\title{
Osteocalcin levels in a healthy population of western Mexico and comparison with populations from around the world
}

Jesús Nieto-Flores, José Rafael Villafán-Bernal, Edgar Alfonso Rivera-León, Iris Monserrat LlamasCovarrubias, Mercedes Elvira González-Hita, Juan Luis Alcalá-Zermeno and Sergio Sánchez-Enríquez

Universidad de Guadalajara, Centro Universitario de Ciencias de la Salud, Guadalajara, Jalisco, Mexico

\begin{abstract}
Introduction: Osteocalcin has been shown to have an inverse relationship with blood glucose, insulin resistance and adiposity. Objective: To determine osteocalcin normal serum concentration in Mexican healthy adults and compare it with values reported in other populations. Method: Carboxylated and undercarboxylated osteocalcin serum concentrations were determined in 100 healthy adults by means of enzyme immunoassay; osteocalcin total concentration was calculated. A descriptive comparison was made with other populations' values reported in the literature. Results: Carboxylated and undercarboxylated osteocalcin median concentrations were $3.22 \mathrm{ng} / \mathrm{mL}$ and $1.61 \mathrm{ng} / \mathrm{mL}$, respectively. Mean total osteocalcin was $7.40 \pm 5.11 \mathrm{ng} / \mathrm{mL}$. There was no significant difference between the osteocalcin values in our population and those of populations where similar quantification methods to ours were used. Conclusion: Osteocalcin total serum concentration mean in the analyzed population was $7.40 \mathrm{ng} / \mathrm{mL}$. There are subtle variations between populations that are attributable to genetic and population factors; however, the quantification method was the only variable that was shown to significantly influence on osteocalcin levels in healthy populations.
\end{abstract}

KEY WORDS: Osteocalcin. Serum concentration. Osteogenesis. Blood glucose.

\section{Introduction}

Osteocalcin (OC) is a 49-amino acid peptide encoded in the BGLAP gene and is produced mainly by osteoblasts. This peptide is the second most abundant in bone, only after collagen. OC has osteogenic and hormonal functions. After its synthesis in the rough endoplasmic reticulum, $\mathrm{OC}$ is carboxylated at its glutamic acid residues in positions 17, 21 and 24, respectively, yielding carboxylated osteocalcin (cOC) as a result, which comprises $95 \%$ of total body OC. ${ }^{1}$ This carboxylation is mediated by a vitamin K-dependent carboxylase and this process confers $\mathrm{COC}$ high affinity for hydroxyapatite. Osteocalcin undercarboxylated (ucOC) fraction can be obtained by partial carboxylation during its synthesis or $\mathrm{COC}$ de-carboxylation generated by the acidic microenvironment induced by osteoclasts during bone resorption. ${ }^{2}$
OC functions will depend on the tissue where it acts and on the degree of carboxylation. In the bone, OC increases bone formation and improves its mechanical properties while stimulating osteoclastic differentiation. The net effect is bone formation, remodeling and maintenance..$^{2,3}$

Initially, OC was considered a hormone that was exclusive to bone metabolism; however, thanks to the studies carried out by Lee et al., an association between energy and bone metabolism was demonstrated, where ucOC has an inverse relationship with blood glucose, insulin resistance and adiposity. In addition, OC increases insulin expression and secretion in pancreatic $\beta$ cells and adiponectin secretion by adipocytes. ${ }^{1}$ In patients with diabetes mellitus there are decreased levels of ucOC, and these are negatively correlated with weight, body mass index and fasting plasma glucose levels, and for this reason OC has been proposed as a predictor and a therapeutic
Correspondence:

Sergio Sánchez-Enríquez

E-mail: serlucis@ hotmail.com
Date of reception: 14-04-2016

Date of acceptance: 09-05-2016

DOI://dx.doi.org/10.24875/GMM.M18000128
Gac Med Mex. 2018;154:141-145

Contents available at PubMed www.gacetamedicademexico.com 
option for this disease. ${ }^{2}$ On the other hand, OC has been implied in fertility, since it is significantly correlated with testosterone free levels in the male population. ${ }^{2}$ Finally, OC might influence on the development of affective and anxiety disorders, since it has been shown to inhibit the production of GABA by the striatum and hippocampus, where it increases monoaminergic transmitter synthesis, whereby it decreased anxiety and depression in a murine model. ${ }^{2,4}$

The exact mechanism by means of which $\mathrm{OC}$ carries out this wide range of functions is unknown. However, the GPRC6A receptor has been identified as a possible exclusive mediator of $\mathrm{OC}$ functions, since the phenotype of GPRC6A-knockout mice is very similar to that of osteocalcin-knockout mice. In turn, signaling pathways that are stimulated by said receptor have been identified to ultimately induce the expression of genes that improve the metabolic profile, such as peroxisome proliferator-activated receptor gamma (PPAR- $\gamma$ ) and of genes that increase steroidogenesis, such as cAMP response element-binding (CREB), all this by a $G$ protein-linked mechanism. Nevertheless, this receptor's molecular structure has not been described, and neither has its binding mechanism with $\mathrm{OC}$ and, therefore, it remains merely a possibility. ${ }^{2}$

Currently, $\mathrm{OC}$ is used as a marker of bone formation both for research and clinical purposes. Among its applications, determination of the risk for fractures, of therapeutic response to bisphosphonates and hormone replacement, monitoring of bone metastatic activity, monitoring of myeloma multiple and response to growth hormone administration in disorders due to its deficiency, among others, stand out. ${ }^{5-8}$

\section{Method}

One-hundred clinically healthy adults were recruited at the Diabetes and Metabolic Syndrome Detection Program of the Biochemistry Laboratory, Centro Universitario de Ciencias de la Salud, Universidad de Guadalajara, in Jalisco, Mexico. The study was approved by the Ethics, Research and Biosafety Committee of the center and adhered to the standards and ethical principles established in the Declaration of Helsinki, ratified at the $18^{\text {th }}$ World Medical Assembly. After the informed consent was signed, medical history was obtained and physical examination performed, with relevant measurements taken in order to rule out arterial hypertension, overweight, obesity and metabolic syndrome, using the criteria and methods stipulated by the Joint National Committee on the Prevention,
Detection, Evaluation and Treatment of High Blood Pressure $7^{\text {th }}$ Report, the World Health Organization and the Adult Treatment Panel III, respectively. ${ }^{9-11}$

After a 12-h fasting period, a blood sample was obtained for biochemical determinations. Individuals meeting the criteria for type 2 diabetes, metabolic syndrome or systolic high blood pressure, or who indicated any pathology that might alter OC levels or who consumed medications that might influence on OC levels, such as insulin, glucocorticoids, oral contraceptives, vitamin $\mathrm{D}$, vitamin $\mathrm{K}$, bisphosphonates, calcium, calcitriol, thiazolidinediones or anticoagulants, were excluded.

All obtained blood samples were centrifuged and separated to subsequently store the sera at $-20{ }^{\circ} \mathrm{C}$. $\mathrm{COC}$ determination was performed by means of sandwich-type enzyme immunoassay (EIA), which uses monoclonal antibodies directed against fragments containing the 17- $\gamma$-carboxyglutamic COC-specific residue (Gla-OC MK-111®, Takara Bio Inc., Japan). This test has intra- and inter-assay coefficients of 3.3-4.8 and 1.0-2.4, respectively. The assay for ucOC uses the same technique and targets fragments that contain the glutamic 21 and 24 residues, which are ucOC-specific with $5 \%$ of cross-reactivity with cOC (Glu-OC MK-118®, Takara Bio Inc., Japan). This test has intra- and inter-assay coefficients of 4.6-6.7 and 5.7-9.9, respectively. For tOC calculation, arithmetic sum of the $\mathrm{COC}$ and $\mathrm{uCOC}$ values was performed, as indicated in different publications..$^{12-15}$

Statistical analysis was carried out with the SPSS version 18.0 and Graphpad Prism version 5 programs. A $95 \%$ level of confidence and a $p$-value $<0.05$ was considered to be significant. Kolmogorov-Smirnov test was used to verify for normal distribution in the determined variables. Arithmetic mean, standard deviation, standard error of the mean and ranges were obtained. For inferential analysis, Student's t-test was used for variables with normal distribution, whereas for variables not normally distributed, chi-square, Kruskal-Wallis and Mann-Whitey $U$ tests were used.

\section{Results}

cCO and ucCO concentrations were quantified in 72 women and 22 men that were clinically healthy and had an average age of $45.4 \pm 5.9$ years, and total osteocalcin (tOC) levels were calculated. Median $\mathrm{COC}$ and ucCO concentrations were $3.22 \mathrm{ng} / \mathrm{mL}$ and $1.61 \mathrm{ng} / \mathrm{mL}$, respectively; mean serum tOC concentration was 
$7.40 \pm 5.11 \mathrm{ng} / \mathrm{mL}$ (Fig. 1). Study subjects' characteristics are presented in table 1.

With the purpose to compare healthy Mexican population tOC levels, information about this parameter was collected in healthy controls from different populations (Table 2), both from analytical cross-sectional studies and case-control studies. Median tOC concentration in Australian population was $6.6 \mathrm{ng} / \mathrm{mL} ;{ }^{16}$ in Turks, $8.82 \pm 4.03 \mathrm{ng} / \mathrm{mL}$ and in North Americans, $4.4 \pm 1.4 \mathrm{ng} / \mathrm{mL}^{17,18}$ In Moroccan population, mean tOC serum values was $18.3 \pm 5.5 \mathrm{ng} / \mathrm{mL}$, in Brazilians, $33.2 \pm 5.1 \mathrm{ng} / \mathrm{mL}$, and in Austrians, $40.0 \pm 21.3 \mathrm{ng} / \mathrm{mL}$, which are significantly higher values in comparison with those obtained in our population $(p<0.01$, $p<0.001$ and $p<0.0001$, respectively)..$^{19-21}$

\section{Discussion}

Osteocalcin main clinical utility is as a bone turnover marker that can be applied to different pathologies, such as osteoporosis, Paget's disease and bone neoplasms. ${ }^{2,3,22,23}$ In addition, OC can be employed as an indicator of cardiovascular risk, ${ }^{24}$ metabolic risk and glycemic control in diabetic patients..$^{25}$ Consequently, we consider highly important for a specific reference range in the Mexican population to be available.

In our study, $\mathrm{COC}$, ucOC and $\mathrm{tOC}$ serum concentration normality ranges were $3.22 \mathrm{ng} / \mathrm{mL}, 1.61 \mathrm{ng} / \mathrm{mL}$ (medians) and $7.40 \pm 5.11 \mathrm{ng} / \mathrm{mL}$ (mean), respectively. OC serum concentration values depend on different factors, with genetic variations, ethnicity, age, gender, vitamin $D$ and geography standing out. Studies on twins have demonstrated that $80 \%$ of variation in serum concentration depends on genetic expression, ${ }^{26}$ which might explain variations between ethnic groups: smaller in Caucasians and larger in Afro-descendants. ${ }^{27}$ Age also influences on OC level: it is higher in children and adolescents, who have more osteogenic capacity, than in adults. Women usually have lower osteocalcin concentration in the premenopausal period because estrogen has an inhibitory effect on OC synthesis, and there is an expected OC increase in postmenopause. Vitamin $D$ is a stimulator of BGLAP gene transcription and, consequently, osteocalcin concentrations are lower in populations with low intake of it or less exposure to sunlight. ${ }^{28,29}$ Finally, $\mathrm{OC}$ is broken down by renal enzymes, and kidney function deterioration will therefore increase circulating levels of this hormone. ${ }^{27}$

When comparing our values with those of other populations of the rest of the world, we didn't find

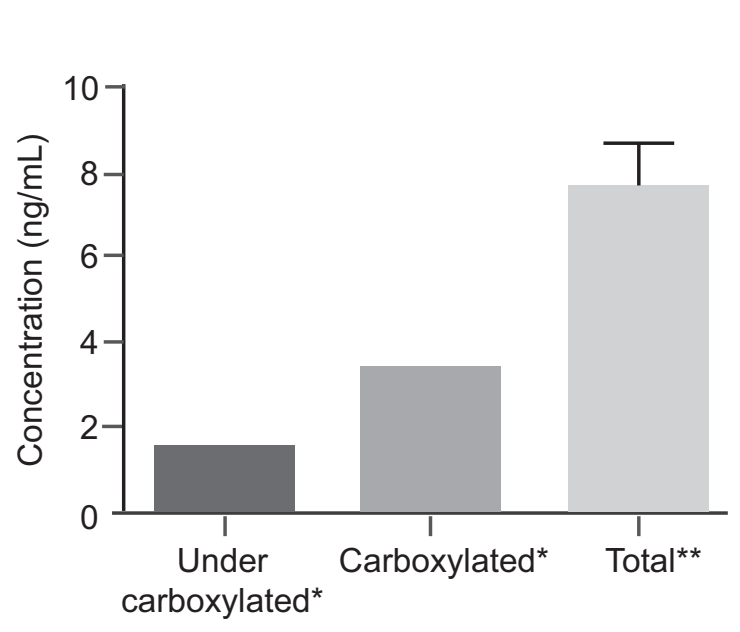

Osteocalcin

Figure 1. Osteocalcin variants serum concentrations. "Median. ${ }^{* *}$ Mean.

Table 1. Clinical and demographic characteristics of 100 healthy adults who had osteocalcin variants serum concentration quantified

\begin{tabular}{lr}
\hline Gender & $n$ \\
Male & 22 \\
Female & Median $\pm S D$ \\
& 78 \\
Age (years) & $72.13 \pm 14.8$ \\
Weight $(\mathrm{kg})$ & $161.05 \pm 7.4$ \\
Height $(\mathrm{cm})$ & $113.25 \pm 10.96$ \\
Systolic blood pressure $(\mathrm{mmHg})$ & $74.9 \pm 7.51$ \\
Diastolic blood pressure $(\mathrm{mmHg})$ & \\
\hline
\end{tabular}

statistical differences with values obtained in Australians, Turks and North Americans. However, the values that showed to be significantly different were those obtained in Moroccan, Brazilian and Austrian populations. On the basis of the broad heterogeneity between these populations, we could not attribute the differences to genetic and environmental factors, since these human groups broadly differ in the diet they consume, their genetics and the geography of the place where they live, in spite of which their normality ranges do not significantly differ between each other, as it would be expected. What seems to mark between-groups difference appears to be the method to quantify the hormone, since two large groups can be established: those that used enzyme immunoassay, ELISA and radioimmunoassay versus those that used immunoradiometric assay and electrochemiluminescence. There are numerous methods to quantify OC levels, all of which use the antigen-antibody interaction as the means to identify the molecule of 
Table 2. Comparison of osteocalcin concentrations and some clinical and demographic variables between different populations

\begin{tabular}{|c|c|c|c|c|c|c|c|}
\hline Population & tOC (ng/mL) & Age (years) & BMI $\left(\mathrm{kg} / \mathrm{m}^{2}\right)$ & $\mathrm{M} / \mathrm{F}$ & $\mathrm{SCr}(\mathrm{mg} / \mathrm{dL})$ & Method & Reference \\
\hline $\begin{array}{l}\text { Mexican } \\
(n=100)\end{array}$ & $7.40 \pm 5.11$ & $45.4 \pm 5.9$ & $27.46 \pm 5.14$ & $22 / 78$ & $0.88 \pm 0.2$ & EIA & $\frac{\infty}{5}$ \\
\hline $\begin{array}{l}\text { Australian } \\
(n=37)\end{array}$ & $6.6^{\dagger}$ & $62 \pm 3^{\star \star \star}$ & $25 \pm 1^{*}$ & $20 / 17$ & $1.0 \pm 0.07$ & RIA & 16 \\
\hline $\begin{array}{l}\text { Turkish } \\
(n=20)\end{array}$ & $8.82 \pm 4.03^{\dagger}$ & $54.35 \pm 3.17^{\star \star *}$ & $26.73 \pm 4.07^{\dagger}$ & $0 / 20$ & -- & ELISA & $\begin{array}{l}17 \\
2 \\
\text { (c) }\end{array}$ \\
\hline $\begin{array}{l}\text { North American } \\
(n=20)\end{array}$ & $4.4 \pm 1.4^{\dagger}$ & $54.6 \pm 11.7^{\star \star \star}$ & $27.8 \pm 2.7^{\dagger}$ & $10 / 10$ & -- & $\mathrm{RIA}$ & 18 \\
\hline $\begin{array}{l}\text { Moroccan } \\
(n=35)\end{array}$ & $18.3 \pm 5.3^{*}$ & $53.2 \pm 8^{\star \star *}$ & $25.4 \pm 4.1^{\dagger}$ & $35 / 0$ & -- & ECL & $\frac{919}{5}$ \\
\hline $\begin{array}{l}\text { Brazilian } \\
(n=24)\end{array}$ & $33.2 \pm 5.1^{\star *}$ & $46.5 \pm 1.1^{\dagger}$ & $26.5 \pm 0.6^{\dagger}$ & $10 / 14$ & -- & IRMA & $\frac{21}{\frac{2}{\ddagger}}$ \\
\hline $\begin{array}{l}\text { Austrian } \\
(n=588)\end{array}$ & $40.0 \pm 21.3^{\star \star *}$ & $84.2 \pm 6.3^{\star \star \star}$ & $25.4 \pm 4.8^{\star \star \star}$ & -- & -- & ECL & $\frac{20}{2}$ \\
\hline $\begin{array}{l}{ }^{*} \mathrm{p}<0.01,{ }^{* \star} \mathrm{p}<0.001 \\
\text { tOC, total osteocalcin; } \\
\text { IRMA, immunoradiome }\end{array}$ & $\begin{array}{l}<0.0001,{ }^{+} \text {Non-signi } \\
\text { body mass index; M } \\
\text { ssay. }\end{array}$ & $\begin{array}{l}\text { alue. } \\
\text { e/female; SCr, serum }\end{array}$ & ne; EIA, electroim & say : $B$ & mmunoassay: EC & chemilum & $\frac{E}{\square}$ \\
\hline
\end{tabular}

interest (OC in our case) and can be divided into 3 groups: radiation-based, enzyme-based and electrochemiluminescence-based. The first group includes radioimmunoassay and immunoradiometric assay, which employ radiolabeled antibodies that are quantifiable when they bind to the antigen $(\mathrm{OC}) .^{30} \mathrm{En}$ zyme-based assays are the enzyme-linked immunosorbent assay (ELISA) and enzyme immunoassay, which quantify the antigen using antibodies linked to an enzyme; after the antigen-antibody reaction, a substrate for the enzyme is added, which elicits a measurable colorimetric reaction. ${ }^{31}$ Finally, electrochemiluminescence is based on the binding of antibodies labeled with a material that after an electric stimulus elicits a quantifiable luminescent reaction. ${ }^{32}$

High correlation has been demonstrated between OC values obtained by ELISA, enzyme immunoassay and radioimmunoassay. ${ }^{33}$ However, immunoradiometric assay-obtained values are often 3 to 4 -fold higher. We didn't find trials correlating the electrochemiluminescence method with ELISA, enzyme immunoassay and radioimmunoassay; still, ranges up to 5 -fold higher are reported using this method. ${ }^{34}$ Possible reasons for these discrepancies revolve around the particular sensitivity and specificity of each method and of the laboratory that produces the kit, as well as on the type of antibodies used to identify the molecule.

Since intact $O C$ is an unstable molecule, quantification methods use fragment determination, particularly the combination of aminoterminal (aa. 1-19) and middle segments (20-43), since this is the part of the molecule that contains the carboxylable glutamic acid residues, which is another reason that accounts for measurement variability. ${ }^{22,33}$

To our knowledge, this is the first description of $\mathrm{COC}, \mathrm{ucCO}$ and tOC serum concentrations in healthy individuals of a Mexican population. We are aware that these values were obtained in a population subgroup represented by residents of western Mexico; however, since there is no national consensus they can be used as a reference for subsequent research in different regions of the country.

The factors that affect $\mathrm{OC}$ concentrations are diverse; however, the quantification method appears to be the most important, and standardizing the procedure for the measurement of this hormone is therefore imperative.

\section{Funding}

This work was supported by Consejo Estatal de Ciencia y Tecnología Jalisco-Universidad de Guadalajara (COECyTJAL), project 25-718-2008, granted to Doctor Sergio Sánchez-Enríquez.

\section{References}

1. Lee NK, Sowa H, Hinoi E, Ferron M, Ahn JD, Confavreux C, et al. Endocrine regulation of energy metabolism by the skeleton. Cell. 2007: 130(3):456-469.

2. Li J, Zhang H, Yang C, Li Y, Dai Z. An overview of osteocalcin progress. $J$ Bone Miner Metab. 2016;34(4):367-379.

3. Chapurlat RD, Confavreux $\mathrm{CB}$. Novel biological markers of bone: from bone metabolism to bone physiology. Rheumatology (Oxford). 2016; 55 (10):1714-1725. 
4. Oury F, Khrimian L, Denny CA, Gardin A, Chamouni A, Goeden N, et al. Maternal and offspring pools of osteocalcin influence brain development and functions. Cell. 2013:155(1):228-241.

5. Power MJ, Fottrell PF. Osteocalcin: diagnostic methods and clinical applications. Crit Rev Clin Lab Sci. 1991:28(4):287-335.

6. Civitelli R, Armamento-Villareal R, Napoli N. Bone turnover markers: understanding their value in clinical trials and clinical practice. Osteoporos Int.2009:20(6):843-851.

7. Seibel MJ. Biochemical markers of bone turnover: part I: biochemistry and variability. Clin Biochem Rev. 2005:26(4):97-122.

8. Seibel MJ. Biochemical markers of bone turnover: Part II: Clinical applications in the management of osteoporosis. Clin Biochem Rev. 2006: 27(3):123-138

9. Chobanian AV, Bakris GL, Black HR, Cushman WC, Green LA, Izzo JL, et al. The seventh report of the Joint National Committee on Prevention, Detection, Evaluation, and Treatment of High Blood Pressure: the JNC 7 Report. JAMA. 2003:289(19):2560-2572.

10. Organización Mundial de la Salud. Dieta, nutrición y prevención de enfermedades crónicas. Serie de Informes Técnicos Núm. 797. Ginebra, Suiza: OMS: 1990.

11. National Institutes of Health. Third Report of the National Cholesterol Education Program Expert Panel on Detection, Evaluation, and Treatment of High Blood Cholesterol in Adults (Adult Treatment Panel III). NIH Publication 01-3670. Bethesda, Md: National Institutes of Health; 2001.

12. Price PA, Lothringer JW, Nishimoto SK. Absence of the vitamin K-dependent bone protein in fetal rat mineral. Evidence for another gamma-carboxyglutamic acid-containing component in bone. J Biol Chem. 1980:255(7):2938-2942.

13. Koyama N, Ohara K, Yokota H, Kurome T, Katayama M, Hino F, et al. A one step sandwich enzyme immunoassay for $\gamma$-carboxylated osteocalcin using monoclonal antibodies. J Immunol. Methods. 1991;139(1):17-23.

14. Garnero P, Grimaux M, Demiaux B, Preaudat C, Seguin P, Delmas PD Measurement of serum osteocalcin with a human-specific two-site immunoradiometric assay. J Bone Miner Res. 1992;7(12):1389-1398.

15. Vergnaud P, Garnero P, Meunier PJ, Bréart G, Kamihagi K, Delmas PD Undercarboxylated osteocalcin measured with a specific immunoassay predicts hip fracture in elderly women: the EPIDOS Study. J Clin Endocrinol Metab. 1997:82(3):719-724.

16. Pietschmann P, Schernthaner G, Woloszczuk W. Serum osteocalcin levels in diabetes mellitus: analysis of the type of diabetes and microvascular complications. Diabetologia. 1988:31(12):892-895.

17. Akin $\mathrm{O}, \mathrm{Göl} \mathrm{K,} \mathrm{Aktürk} \mathrm{M,} \mathrm{Erkaya} \mathrm{S.} \mathrm{Evaluation} \mathrm{of} \mathrm{bone} \mathrm{turnover} \mathrm{in} \mathrm{postmeno-}$ pausal patients with type 2 diabetes mellitus using biochemical markers and bone mineral density measurements. Gynecol Endocrinol. 2003:17(1):19-29.

18. Rosato MT, Schneider SH, Shapses SA. Bone turnover and insulin-like growth factor I levels increase after improved glycemic control in noninsulin-dependent diabetes mellitus. Calcif Tissue Int. 1998:63(2):107-111.

19. Achemlal L, Tellal S, Rkiouak F, Nouijai A, Bezza A, Ghafir D, et al. Bone metabolism in male patients with type 2 diabetes. Clin Rheumatol. 2005:24(5):493-496
20. Dobnig H, Piswanger-Sölkner JC, Roth M, Obermayer-Pietsch B, Tiran A, Strele A, et al. Type 2 diabetes mellitus in nursing home patients: effects on bone turnover, bone mass, and fracture risk. J Clin Endocrinol Metab. 2006:91(9):3355-3363.

21. Cutrim DM, Pereira FA, De-Paula FJ, Foss MC. Lack of relationship between glycemic control and bone mineral density in type 2 diabetes mellitus. Braz J Med Biol Res. 2007:40(2):221-227.

22. Shankar S, Hosking DJ. Biochemical assessment of Paget's disease of bone. J Bone Miner Res. 2006:21(Suppl 2):P22-P27.

23. Coleman R, Brown J, Terpos E, Lipton A, Smith MR, Cook R, et al. Bone markers and their prognostic value in metastatic bone disease: clinical evidence and future directions. Cancer Treat Rev. 2008;34(7):629-639.

24. Magni $P$, Macchi $C$, Sirtori CR, Corsi-Romanelli MM. Osteocalcin as a potential risk biomarker for cardiovascular and metabolic diseases. Clin Chem Lab Med. 2016;54(10):1579-1587.

25. Villafán-Bernal JR, Llamas-Covarrubias MA, Muñoz-Valle JF, Rivera-León EA, González-Hita ME, Bastidas-Ramírez BE, et al. A cut-point value of uncarboxylated to carboxylated index is associated with glycemic status markers in type 2 diabetes. J Investig Med. 2014:62(1):33-36.

26. Kelly PJ, Hopper JL, Macaskill GT, Pocock NA, Sambrook PN, Eisman JA. Genetic factors in bone turnover. J Clin Endocrinol Metab. 1991: 72(4):808-813.

27. Hauschka PV, Lian JB, Cole DE, Gundberg CM. Osteocalcin and matrix Gla protein: vitamin K-dependent proteins in bone. Physiol Rev. 1989:69(3):990-1047

28. O'Connor E, Molgaard C, Michaelsen KF, Jakobsen J, Cashman KD. Vitamin D-vitamin $\mathrm{K}$ interaction: effect of vitamin $\mathrm{D}$ supplementation on serum percentage undercarboxylated osteocalcin, a sensitive measure of vitamin K status, in Danish girls.Br J Nutr. 2010;104(8): 1091-1095.

29. Stroud ML, Stilgoe S, Stott VE, Alhabian O, Salman K. Vitamin D-A review. Aust Fam Physician. 2008:37(12):1002-1005.

30. Giton F, Caron P, Bérubé R, Bélanger A, Barbier O, Fiet J. Plasma estrone sulfate assay in men: Comparison of radioimmunoassay, mass spectrometry coupled to gas chromatography (GC-MS), and liquid chromatography-tandem mass spectrometry (LC-MS/MS). Clin Chim Acta. 2010;411(17-18):1208-1213.

31. Leguin RM. Enzyme immunoassay (EIA)/enzyme-linked immunosorbent assay (ELISA). Clin Chem. 2005;51(12):2415-2418.

32. Carrozza C, Corsello SM, Paragliola RM, Ingraudo F, Palumbo S, Locantore $\mathrm{P}$, et al. Clinical accuracy of midnight salivary cortisol measured by automated electrochemiluminescence immunoassay method in Cushing's syndrome. Ann Clin Biochem. 2010;47(Pt 3):228-232.

33. Lee AJ, Hodges S, Eastell R. Measurement of osteocalcin. Ann Clin Biochem. 2000;37(Pt 4):432-446.

34. Levinger JD, Zajac EG. Osteocalcin, undercarboxylated osteocalcin, and glycemic control in human subjects. En: Karsenty G. Translational endocrinology of bone. EE. UU.: Elsevier; 2013. 